\title{
English as a Foreign Language at the University of Yaounde 1: Attitudes and Pedagogic Practices
}

\author{
Eric Ekembe Enongene ${ }^{1}$ \\ ${ }^{1}$ University of Yaounde 1, Cameroon \\ Correspondence: Eric Ekembe Enongene, University of Yaounde 1, Cameroon. E-mail: eric.ekembe@yahoo.com
}

Received: November 15, 2012 Accepted: January 11, 2013 Online Published: February 1, 2013

doi:10.5539/elt.v6n3p57 URL: http://dx.doi.org/10.5539/elt.v6n3p57

\begin{abstract}
Learners' goals and attitudes constitute an essential determinant of how they learn the target language. Whether positive or negative, they determine classroom practices and are affected by what happens in the classroom (Dörnyei 2003). The complex relationship between learners' attitudes and the actual teaching of English as a foreign language at the University of Yaounde 1 challenges the purpose for which English is learned. Given the increasing space and awareness English is gaining around the world, its teaching deserves more attention than is given at the university level in Cameroon. From a survey of 966 students and 27 teachers this paper examines how the attitudes of current EFL learners at the Yaounde 1 University are affected by the actual teaching of English from a process oriented perspective. Teacher practices account for learners' negative attitudes towards English on a significant note. While this has implications for both academic policies and professional training in general, the question of a more situated framework for training is emphasised.
\end{abstract}

Keywords: attitudes, motivation, EFL, learning, teaching, process orientation

\section{Introduction}

Language learning is affected by the physical, social and affective factors. The physical and social factors are determined by space, but affective factors depend more on the learner. While the three are intensively interconnected in determining how learning occurs, affective factors such as attitudes and motivation remain central in the entire process (Gardner \& Lambert 1972). They influence the degree of initiative, willingness, and investment made by the learner and affect learning outcomes at a short and measurable time. The relationship between learners' attitudes and the actual teaching of English as a foreign language at the University of Yaounde 1 challenges the purpose for which English is learnt. Teaching English as a foreign language is essentially intended to enable learners to communicate with a degree of fluency. Learners generally have clearly defined goals for studying English, and are most likely to be sensitive towards the strategies that are employed by the teacher in the classrooms to enable them to attain their goals. If the classroom supports them in realising the goals, they are most likely to develop positive attitudes towards the course (Dörnyei 2003, Ushida 2005) and the purpose for which they are learning the language becomes feasible to them. However, it is not yet very clear whether classroom practices alone can divert learners' attitudes towards English in a situation where the need for the language is steered more by conscious awareness of its increasing value than by the obvious need to communicate. This paper hopes to address questions related to learners' attitudes towards English as a foreign language at the University of Yaounde 1, teaching strategies used by instructors. The paper further intends to examine the relationship between the learners' attitudes and the actual practice of teaching English as a foreign language (EFL) at the University of Yaounde 1.

\subsection{Background to the Teaching and Learning Context}

\subsubsection{The Quest for English in Cameroon}

In a country with over 279 ethnic languages (The Ethnologue 2005), in addition to two colonial languagesEnglish and French, the question of attitudes towards 'the other' languages becomes focal in language research. Negative attitudes towards English in Cameroon in the $20^{\text {th }}$ century have disappeared and the quest for English is witnessing a fast speed. This can be attested not only by the number of English Language centres sprouting everyday in the urban cities of Douala and Yaounde, but also by the number of Francophones rushing for English. For example, Anchimbe (2005) reviews the rate at which francophones are rushing for English education and 
observes that 55\% of pupils in anglosaxon primary schools in Yaounde are Francophones. He further notes that the trend is the same at the university level where many Francophones are enrolling in Master's Degree studies in English Language, Linguistics and Literary Studies. Although no recent studies have been conducted to shed light on the situation seven years on, it is worth mentioning that the tendency is estimated to be up to $75 \%$. For example, out of 37 students in a Form Four class I taught in a private school in Yaounde in 2009, only one of the students was Anglophone. This rush for English and anglosaxon education by Francophones in Cameroon is explained by Simo Bobda (2001: 5):

First, the economic crisis that hit Cameroon and the consequent decline in educational standards have diverted attention on many children to new professional and educational openings in North America and various parts of the world where English is the gateway. Secondly, with the advent of globalisation, English has reinforced its position as the international language. Thirdly, many Francophone African youths are disenchanted with the immigration laws of France, which used to be the first readily available destination. Fourthly, new political developments in countries like South Africa have opened new dimensions, where English will be needed.

It is worth emphasising that English today is not only a language. It is even more than business. It is more of a way of life (identity construction) and even a means to other valuables. With this rush for English observed by Anchimbe and Simo Bobda, one expects to find either a corresponding or increasing zeal in the quest for English in higher institutions of learning especially as students at this level are more informed about its importance on the world's agenda. Paradoxically, the relative value the language has achieved seems to be down played by the way through which acquisition is managed at the university level where more is expected.

\subsubsection{English as a Foreign Language (EFL) at the University of Yaounde 1}

A general kind of confusion is expressed on the nomenclature and content of English as a foreign language teaching at the university level in Cameroon. While the title, 'Bilingual Training' or 'Formation Bilingue', is contextually understood to mean English for the purpose of bilingualism, the basic teaching politics of the course is often misconstrued by stakeholders. It is important to clarify that the term 'Bilingual Training' does not seek to explain the intention to train students to communicate in two languages, but rather to enable students to communicate in the 'other' official language given that students at this level can already speak more than two/three languages. Needless to say that Cameroon practices official bilingualism where English and French are used for official transactions. Thus, the appellation 'Bilingual Training' follows the official bilingualism scheme put in place by the Cameroonian government in 1998, an implementation of the 1996 Constitution which states in its article 12 that the official languages of Cameroon shall be English and French. This course, up to 2006, had no clear course outline and teachers were left with the democracy to teach whatever they felt they could teach well and not what was considered relevant to the students. The creation of specific units to cater for the course saw the birth of its maiden course outline. According to the course outline for the Faculty of Arts, Letters and Social Sciences,

Bilingual Training (English for Francophones) is supposed to enable students to communicate appropriately in English in relevant domains in life. At the end of the three year course, students are expected to produce and understand spoken and written texts using good English. To attain this global objective, the course will cover grammar, vocabulary and expression, pronunciation and writing (Course Outlines for English, Faculty of Arts, Letters and social Sciences).

The only communicative skill mentioned by programme is writing, while listening, reading, and speaking receive less attention, although the programme expects the learners 'to produce spoken and written texts using good English'. Although the programme intends to be communicative, the implementation of a communicative scheme is evaded with the argument that the classes are generally too larger for any communicative activities and that Francophone Cameroonians are rowdy and disorderly such that the introduction of communicative activities will only result in an unbearable chaos in the classroom. Large classes actually constrain the effectiveness with which communicative activities can be introduced in the classroom, yet the conceptualisation of the course does not seem to notice it. There is a general confusion between stakeholders whether the course lies within the framework of English for Specific Purposes (ESP), English for Occupational Purposes (EOP) or English for Academic Purposes (EAP). Some brief clarification on this issue is necessary here, but I will first demonstrate the confusion noticed in the expectations of the course across different departments of the Faculty of Arts, Letters and Social Sciences.

The 2008 Bachelor, Master, Doctorate (BMD) programmes for the Faculty of Arts carries different expectations and objectives of the course. For example, in the second year of the Theatre Arts Department, the objectives 
expect the course to upgrade learners' general competence in the two official languages, while the intentions in the History and Geography Departments require that learners be furnished with linguistic knowledge that can enable them to learn terminology related to History so as to easily understand other courses (des connaissances linguistiques leur permettanat de mieux s'adapter au vocabulaire historique et suivre aisement les cours dans les deux langues officielles). The contents of the course, the programme specifies, is "Origine du Bilinguisme au Cameroun; Grammaire; Vocabulaire" (see Programmes LMD 2007 - 2008: 125). In the first year of the Geography Department, the course requires students to master geography-related terminology with a focus on Traduction, grammaire, vocabulaire geographique, expression ecrite et orale (translation, grammar, geographical terminology, written and spoken expression) (p. 105).

This confusion implies that different Departments in the Faculty have the autonomy to define the course as they find relevant to their students, although this is not actually the case. The confusion is only a problem of understanding what is expected of the course given that no clear consensus has been reached on what the course is and is not. The result of this confusion is that some departments unconsciously define the course in terms of English for Academic Purposes while others see it as English for Specific Purposes (ESP).

English for academic purposes (EAP), a sub-domain of English for Specific Purposes (ESP), is generally done in formal academic contexts (Carkin 2005). Carkin identifies two sub-divisions of EAP: English for General Academic Purposes (EGAP) and English for Specific Academic Purposes (ESAP). The main difference between the two is that EGAP emphasizes 'common core' skills and activities where English is taught for general academic purposes, across multiple disciplines, and includes learning and study skills components of broadly relevant academic skills. He insist that the general purpose is largely associated with lower level EAP courses in which students are preparing for later work in disciplinary contexts. In contrast, he argues that ESAP emphasizes higher order skills, student development, and authentic text and features while working within specific epistemological traditions associated with different disciplines. Specifically, he observes that, whether ESAP of EGAP, the general focus is on instruction which represents highly pragmatic approach to learning, encompassing needs analysis, evaluation, academic skills, disciplinary content, and tasks in support of students learning in tertiary education.

In view of this explanation, English for Bilingual Training does not actually fit within the focus of EAP as supposed by Safotso (2011), especially as teaching and administration at the University of Yaounde 1, and other Cameroonian universities where the course is offered, are fundamentally handled in French except in the Departments of English Modern Letters where instruction is in English. On the contrary, it is the teaching of French to Anglophones that appropriately fits within the description of French for Academic Purposes. Given that government's intention in introducing the bilingual scheme in Cameroonian universities was to ensure smooth integration between the two cultures through official languages, the description of general communicative English is what actually translates such intention.

It is in this context where one expects to find serious integrative motives for learning English given that both Anglophones and Francophones sit on the same benches, yet this is not actually the case. It has already been noted that this course lacks a practical focus and is predominantly examination-inclined. In this case, students consider it more or less, an obstacle to their early completion of a degree and, therefore, put in much efforts in succeeding in the course 'rather than actually speaking the other official language' (Anchimbe 2006). It is not actually clear whether the reason for which the objectives of the course are deviated from communication focus to examination focus can be the result of learners' attitudes or its pedagogical practice. This is what this study hopes to clarify.

\section{Trends in Attitudes}

Attitudes are general personality factors, which determine values and worth placed on a target language desired by an individual. In considering learners behaviour towards the target language, attitudes and motivation are concomitantly explored such that the study of one includes the study of the other. This is because positive attitudes are argued to increase motivation (Gardner \& Lambert 1972) perhaps in a causal relationship, although some contrary views exist (see Machiavellian motivation by Oller \& Perkins 1978). From the perspective of needs and drives, Brown (1980) explains motivation as "an inner drive, impulse, emotion, or desire that moves one to a particular action" which is believed to be environmentally conditioned. According to this, he identifies six human needs which lead to motivation. For example, the need for exploration- probing the unknown, the need for manipulation- for operating on the environment and causing change as well as the need for ego enhancement, for the self to be known and to be accepted and approved by others. These are seen to be environmentally conditioned such that, the need for causing change, for example, must be in accordance with 
some immediate environmental problem which the learner identifies and feels rewarded if he successfully solves.

Therefore, the immediate problems of the environment and the expectation for reward can instigate motivation of some sort in the learner. This has been the commonly 'instrumental' account of motivation proposed by Lambert \& Gardner (ibid). Apart from the idea of reward, learners might feel the need to identify with a target culture and consequently be motivated to learn their language. This is described in the literature as integrative motivation (Gardner 1985). Gardner (2006: 11) explains that because integrativeness includes the openness to cultural identification as a component, it seems likely that it may be more associated with attaining the ultimate level of achievement than other motivational types that lack this component.

In actual terms, sufficient evidence accrues to the fact that integrative motivation is more beneficial to learning the target language than instrumental motivation. This traditional conception of motivation has been criticised on the grounds that the idea of 'integrativeness' is central in L2 contexts and may not fully apply to a foreign language context. For example Dörnyei (1990) holds that Chinese's quest for English is motivated by the intellectual and cultural importance of the English language and not necessarily by the urge to be identified with the British or Americans. Equally, instrumental motivation has been argued to be dynamic such that it becomes difficult to draw any specific conclusions on it in generic terms. For example, Smit and Dalton (2000) hold that instrumental drives change according to the benefits, which the learner finds important at a given moment. Research within this traditional perspective has sought to establish a correlation between attitudes, motivation and achievement in the target language. In fact, Dörnyei, Csizer, and Neineth (2006: 68ff) estimate the cardinal role of the learner's attitudes towards the learning situation and observe that it is the influence of the educational context on the individual's attitudes that influences the individual's level of motivation.

Ushida (2005) investigated the role of students' attitudes and motivation in second language learning in online language courses, using Gardner and MacIntyre (1993) socio-educational framework. He sought to answer questions related to (a) patterns of motivation and attitudes toward the study of French and Spanish, (b) the relationship between attitudes and motivation on the one hand, and online learning on the other hand, (c) factors affecting students' attitudes and motivation as well as success in the study and learning of French and Spanish in an online course. Through questionnaire and descriptive data, tests on background information, measures of attitudes and motivation, measures of learning behaviour and course participation, measures of outcomes, he found out that learners' attitudes grew more positively over time in all three contexts and that cultural learning materials and assignments which were well designed to target students' experiences contributed to an improvement in learners' attitudes towards the target language. He also found out that learners who had positive motivation and attitudes participated actively in the online chat and performed well in the course. This led him to suggest that if students like the teacher, they enjoy the class, are satisfied with their learning experiences, and have positive behavioural attitudes toward the target language regardless of the instructional format. Consequently, teachers can be influential in affecting students' motivation and attitude in creating a learning community in which students can study a language with less anxiety.

In a similar perspective, Rodiki (2006) sought to relate attitudes of children and their motivation to their performance in order to establish a relationship in Listening and Speaking. He sampled 250 pupils and, through ANOVA analysis, established a statistical significance between attitudes, motivation and learning tasks. In concrete terms he observed that children who liked English lessons at school did not find it hard; they thought of it as interesting and fun and therefore performed better than others. Rodiki quotes Wilhem (1999) as intimating that there is sufficient evidence to support the correlation between the positive attitude about a language and high achievement. Bernaus, Masgoret, Gardner, and Reyes (2004) investigated the effect of 114 immigrant learners' cultural background on affective variables in learning Catalan, Spanish, and English with the use of questionnaire based on Garner's Attitude/Motivation Test Battery (AMTB). Through factor analysis and 'split-plot' analysis of variance, they establish an intensive relationship between attitudes, integrative motivation and the anxiety of students, achievement in the language of study. Ushida (2005) summarises that this Gardnerian stream of researchers are more interested in the causal relationships among possible individual-difference variables with various achievement measures. According to Smit and Dalton (2000), this view supposes that only a positive attitude towards the target language community can lead to integrativeness, thus contributing to an overall greater motivation in language learning.

However, current research in the domain tends to be shifting from this socio-cultural dimension to a more operationalised perception of the concept (Smit \& Dalton 2000). Two major views are dominant in this motivational renaissance: the cross-context and the process oriented views. The latter initiated by Dörnyei (1990) is supported by Carreira (2005), citing Svanes (1987) who conducted a cross cultural analysis on instrumental and integrative motivation. Svanes found out that European and American students were integratively motivated 
at University in Norway, whereas the Middle Eastern, African, and Asian students were instrumentally motivated. Carreira, however, concluded that the matter of motivation in SLA is not the dichotomy of integrative and instrumental motivation, but rather a multifactoral phenomenon. A more recent cross-contextual study on motivation is provided by $\mathrm{Xu}$ (2010) who establishes a longitudinal profile of 9 Chinese learners of English as they move from an EFL to an ESL context with an integrative purpose. Xu posits the cardinal role of the English learning course in increasing the motivation of learners. This gives a rather process oriented dimension to the study of motivation.

It is believed that areas such as social motivation from a process oriented perspective, a neurobiological explanation of motivation and task motivation can provide more interesting findings than the commonly understood instrumental and integrative motivation and correlation studies (Dörnyei 2003, De Bot , Lowie, and Vespoor 2005, for example). The common belief underlying the educational orientation in L2 motivation research seems to be a focus on motivational sources closely related to the learner's immediate learning situation rather than their overall attitudes toward the target culture (Ushida 2005: 54).

This more dynamic account of the concept explains how taking on the characteristics of beliefs or attitudes as values are internalised. In such a dimension, a person does not only accept values to the point of being willing to be identified with it, but commits himself to the value to pursue it, seek it out, and to want it, finally to the point of conviction (Brown 1980). That is why Dörnyei (2003) thinks that instead of looking, for instance, at how learners' various motivational attributes correlate with language proficiency measures in an L2 course (which would be a typical traditional design), researchers need to look at how motivational features affect learners' various learning behaviours during a course such as their increased willingness to communicate in the L2, their engagement in learning tasks, or their use of learning strategies. It is this view that is adopted in this study.

In line with the dimension proposed by de Bot et al. (2005), a fundamental determinant of motivation identified by Brown (2000) is situational, or task-oriented, which is captured in Mitchell and Myles' (1998: 19) account of motivation. Mitchell and Myles explain three salient components accountable for motivation: the desire to achieve a goal, efforts extended to this direction, and satisfaction as the outcome. In simple terms, a motive or motivating condition is any condition of the individual which initiates and sustains his behaviour, orients him toward the practice of a given task, and which defines adequacy of his activities and the completion of the task. Dörnyei and Otto (1998) provide illustrations on the process-oriented framework for motivating learners. This involves creating the basic motivational condition, generating student motivation, maintaining and protecting motivation and encouraging positive self-evaluation.

Rivers (1964) takes a similar position as Brown and Mitchell and Myles, but specifies that a variety of activities in the foreign language classroom is more likely to develop long term motivation by providing many opportunities to experience success and reward as learners advance toward their goal. The way the learning activities are introduced and their relationship with the learning environment, in this case, determine how learners' actions can be translated into useful learning experience. Littlewood (2006) suggests two ways through which learners can be made to be more committed to a second language. He thinks that learners with more favourable attitudes will wish for more contact with the second language community. To this effect, favourable attitudes will reinforce the extent to which learners perceive communicative needs. He states that when we try to adopt new speech patterns, to some extent we tend to give up markers of our identities in order to adopt those of another cultural group. When the learner has not had any experience with the target culture and learning materials, the teacher determines the learners' attitudes by cultivating a type of image to them. If this image is second-hand, however, it may remain a weak factor compared with more general aspects of motivation, such as enjoyment, stimulation through variety and, above all, the experience of success. He holds that successful learners develop favourable attitudes as the course progresses, and in turn, encourage more success.

Conversely, if learners fail, they may produce negative attitudes, which may lead to further failure. Another important contribution to the role of the classroom in motivating learners is that teachers' attitudes towards their learners have a serious bearing on success or failure in the learning process (Thornbury 2006, Thanasoulas 2002). In any case, it is important to specify that commitment to the course is determined by a stimulus. Summarily, these authors posit the central role of the stimulus the learner is exposed to in the classroom. The stimulus has to be appealing while the wider context of operation needs to give reason for pursuing the course in order to sustain interest and commitment.

\section{Methods}

To obtain data for the study, two different sets of questionnaire with varied factors were used: One for teachers 
and another for students. The teachers' questionnaire was modelled on Brown's (2000) situational or task oriented view of investigating attitudes (also see de Bot et al. 2005). As Dörnyei (2003) argues, students' attitudes towards the target language change in the process of learning depending on how the actual practice of the course impacts their goals. In line with this, the questionnaire was intended to obtain information relating to the following:

- Teachers' knowledge of the students: 7 items (five point-rating-scale)

- Focus on the communicative language teaching: 5 items (five point-rating-scale)

- Teaching activities: 6 items (frequency of occurrence)

- $\quad(\mathrm{Sub})$ skills frequently taught: 5 items (frequency of occurrence)

Reasons for choosing the themes were based on the following arguments: (a) experienced teachers are most likely to have understood the students well and know who the students are and what they want, (b) The nature of teaching and the type of activities and techniques employed by the teacher depends on his knowledge of the students and the nature of the classrooms (see Dörnyei 2002, 2003), (c) the frequency of items taught is expected to be in line with students' convictions about learning English, goals in the course, and the overall objectives of the course.

The 27 teachers sampled (out of the 34 target teachers) were teaching in, at least, three of the fourteen departments that make up the Faculty of Arts, Letters and Social Sciences and the Faculty of Sciences with a minimum teaching experience of 2 years while half of the teachers also taught in the Faculty of Science. Their educational qualification ranged from Master's degree to Ph.D in English studies (Literature and Linguistics). 8 of the 27 teachers had, besides their academic degrees, the Higher Teacher Training Diploma, Grade 2 (commonly known as DIPES II). The rest were post graduate students who had knowledge in language teaching through a course- Methodology in Language Teaching, introduced at the Master's degree level. In terms of professional input, the teachers involved, even the trained teachers, lack basic understanding of the purpose for which language is taught and learned.

Given the task-oriented and situational focus of the study, students' questionnaire was adapted from Gardner's (2004) AMTB and translated into French. Although Gardner (2004) thinks that the test should be used for research at the secondary school level, it was rated good for this study because the practice of English in Cameroonian secondary schools does not differ very much from what obtains at the university, but for the number of hours allocated for English. Equally, secondary school students' attitudes toward English in urban cities in Cameroon, where the universities are located, are basically the same as those of the university students. In spite of the care taken to cover respondents identity, an earlier English version of the questionnaire had revealed a lot of suspicion from the respondents (probably because they wanted to impress the researcher who was present) and so it was translated into French so as to tap students' opinion naturally. The questionnaire was constructed on a five-point-rating scale on the following themes:

- $\quad$ Goals for learning English (3 items)

- Motivation and attitudes (9 items)

- $\quad$ Learning preferences (5 items)

- $\quad$ Beliefs about English (3 items)

- Assessment of their level of English (9 items)

Teachers filled in and returned the questionnaire on the spot while students were given the questionnaire through their class coordinators. They filled in the questionnaire during their free time and returned it through the class delegate. The number of questionnaire fully filled in and returned were as follows:

Table 1.

\begin{tabular}{|l|l|l|l|l|l|l|l|l|l|l|}
\hline History & $\begin{array}{l}\text { Geogra- } \\
\text { phy }\end{array}$ & French & $\begin{array}{l}\text { Socio- } \\
\text { logy }\end{array}$ & Physics & Maths & Bio-Chem & $\begin{array}{l}\text { Animal } \\
\text { Bio }\end{array}$ & $\begin{array}{l}\text { Archae } \\
\text { ology }\end{array}$ & $\begin{array}{l}\text { Computer } \\
\text { Sc. }\end{array}$ & Total \\
\hline 98 & 117 & 97 & 128 & 86 & 69 & 89 & 79 & 109 & 94 & $\mathbf{9 6 6}$ \\
\hline
\end{tabular}

Summarily, both the students' and teachers' questionnaires were constructed on the basis of the self-determination theory, attribution theory, goals theory, and stimulus appraisals (Shumann 1998, Noels 2001, Weiner 1992, Pintrich \& Schunk 2002 cited in Dörnyei 2003) 
Analysis is based on a statistical presentation of participants' opinion in percentages stated in each item of the questionnaire, taking into consideration the frequency of their opinions on various items. It is important to mention that no significant variation in learners' opinions could be attributed to particular departments. Consequently the respondents' opinions are treated here (holistically) and not according to the data from the various departments where participants were sampled.

\section{Results}

\subsection{On Learners' Goals vs Skills Developed by the Teachers}

In every teaching and learning situation, the skills developed by the teachers are expected to be in line with the purpose for which the learners are engaged in the learning activity or the purpose for which the language is learned. Following the survey, while $93.4 \%$ of the learners sampled express general need to study English, $67 \%$ of teachers think that students do not love English. A mismatch between learners' interest in learning English with the skills developed by the teachers is demonstrated below.

Table 2. Learners' goals Vs skills developed by the teacher

\begin{tabular}{|c|c|c|c|c|c|c|c|}
\hline $\begin{array}{l}\text { Learners' } \\
\text { interest }\end{array}$ & $\%$ & \multirow{4}{*}{ Vs } & Skill Developed by teacher & $\begin{array}{l}\text { In AL } \\
\%\end{array}$ & $\begin{array}{l}\text { In ML } \\
\%\end{array}$ & $\begin{array}{l}\text { In FL } \\
\%\end{array}$ & $\begin{array}{l}\text { In NL } \\
\%\end{array}$ \\
\hline speaking & 76.3 & & speaking & - & 11 & 14 & 75 \\
\hline writing & 74.9 & & writing & - & 25 & 31 & 44 \\
\hline grammar & 62.5 & & grammar & 74.1 & 14.82 & 11.11 & - \\
\hline
\end{tabular}

Key: AL-in all lessons; ML- in most lessons; FL-in few lessons; NL- in no lesson

While an over all general interest is demonstrated in speaking and writing (76.3\% and $74.9 \%$ respectively) teachers give preference to teaching grammar (100\%) and generally develop speaking only at $11 \%$ and writing at $25 \%$ in most of the lessons.

\subsection{On Learning Preferences vs Classroom Activities}

The activities introduced in the language classroom have a significant impact on how learners; interests are developed and sustained in the language classroom. It is worth recalling that the success of the activities in cultivating learners' interest, in most of the cases, is determined by the learning context. For example, while adults might generally prefer group/pair work involving more cognitive work to songs, younger learners would want to sing and be engaged in physical activities. The following opinions were expressed by both the learners and teachers with regard to learning preferences and activities introduced in the classroom.

Table 3. Learning preferences Vs classroom activities

\begin{tabular}{|c|c|c|c|c|c|c|c|}
\hline $\begin{array}{l}\text { Learning } \\
\text { Preferences }\end{array}$ & $\%$ & \multirow{6}{*}{ Vs } & $\begin{array}{l}\text { Teaching } \\
\text { activities }\end{array}$ & $\begin{array}{l}\text { In AL } \\
\%\end{array}$ & $\begin{array}{l}\text { In ML } \\
\%\end{array}$ & $\begin{array}{l}\text { In FL } \\
\%\end{array}$ & $\begin{array}{l}\text { In NL } \\
\%\end{array}$ \\
\hline Homework & 52.2 & & Homework & 40.74 & 22.22 & 29.63 & - \\
\hline Games/songs & 49.7 & & & & & & \\
\hline Tasks & 61 & & Games/songs & 25 & - & 37.03 & 62.96 \\
\hline Speaking & 85 & & Pair work & 7.41 & 14.81 & 29.63 & 48.15 \\
\hline $\begin{array}{l}\text { Rule } \\
\text { explanation }\end{array}$ & 61.5 & & Tasks & 04 & 06 & 27 & 63 \\
\hline
\end{tabular}

Key: AL-in all lessons; ML- in most lessons; FL-in few lessons; NL- in no lesson

From the table, there is apparently a match between learners' interest in home work and teachers' responses to it. However, learners' responses at this level can only be evaluated according to how the homeworks are managed. The $49.7 \%$ interest in games/songs experienced only a $25 \%$ reaction from teachers. In the same dimension, pair/group work that facilitates speaking was introduced at $7.41 \%$ in all lessons and at $14.81 \%$ in most of the 
lessons. The $61 \%$ interest in tasks demonstrated by the learners is almost not targeted. Barely, $4 \%$ of the teachers introduce tasks in all lessons, $6 \%$ in most of the lesson, $27 \%$ in few lessons and $63 \%$ in no lesson.

\subsection{Learners' Affective Factors vs Classroom Management}

Learners' interest in language learning is highly dependent on how interesting teaching activities met their expectations and how the total learning environment is managed by the teacher. Success in managing the class largely depends on the teachers' understanding of both the physical and psychological atmosphere of learning. The table below presents learners' feelings and appreciation of learning activities as well as teachers' opinion about the context of learning.

Table 4. Learners' affective factors Vs Classroom management

\begin{tabular}{|c|c|c|c|c|c|}
\hline $\begin{array}{l}\text { Learners' } \\
\text { factors/beliefs }\end{array}$ & $\%$ & \multirow{9}{*}{ Vs } & Classroom management by teachers & Agree & Disagree \\
\hline Lessons are not interesting & 91.9 & & Classes are too large & 100 & - \\
\hline $\begin{array}{l}\text { There are potentials for } \\
\text { improvement }\end{array}$ & 87.36 & & Students disturb a lot in class & 89.3 & 10.7 \\
\hline Teachers don't teach well & 97.32 & & Students don't do their homework & 83 & 12 \\
\hline They need to study Eng. & 89.98 & & $\begin{array}{l}\text { Students only want to satisfy an } \\
\text { academic requirement }\end{array}$ & 89.1 & 8.98 \\
\hline \multicolumn{2}{|l|}{ English is } & & & & \\
\hline difficult & 37.51 & & \multirow[t]{3}{*}{ Students undermine English } & \multirow[t]{3}{*}{96.4} & \multirow[t]{3}{*}{3.6} \\
\hline Like any other lang. & 47.12 & & & & \\
\hline Simple & 15.37. & & & & \\
\hline
\end{tabular}

$100 \%$ of the teachers sampled hold that classes are too large and $97.3 \%$ of them noticed a high degree of rowdiness from students. In contrast $97.32 \%$ of the learners think that teachers do not teach well. While $89.1 \%$ of the teachers have the opinion that students are out only to satisfy an academic requirement, $89.98 \%$ of the learners express a general desire to study English but, $87.36 \%$ of them do not see the classroom as having any impact on their state of English. Equally, $96.4 \%$ of the teachers have the conviction that students undermine English, while $91.9 \%$ of the learners opine that English lessons are not interesting. Surprisingly, a total of $47.12 \%$ of the learners see English as any other language.

\section{Discussion}

A general need to study English, which corresponds with the influx of Francophones into Anglophone primary and secondary schools, is expressed by $89.98 \%$ of the learners sampled. The need ranges from the desire to speak $(76.3 \%)$ and write $(74.9 \%)$. This is not, however, in line with the beliefs teachers hold about the learners and their focus in teaching. $89.1 \%$ of the teachers hold that students are out to satisfy only an academic requirement, while $96.4 \%$ think that students undermine English. Consequently, while $74.1 \%$ of the teachers focus on grammar in all their lessons, teaching speaking is sparingly done at $11 \%$ in most of the lessons and $14 \%$ in few lessons. It should be recalled that the minimal attention given to speaking is even still questionable as what counts as speaking in the language classroom is not fully mastered by the teachers. The contrast between learners' expectations and what is provided has serious implications on their attitudes towards English and classroom management. When learners' goals and expectations are not met in the language classroom, the possibility for frustration is high and tension can arise. The importance of prioritising learners' goals is that it not only helps the learners to reflect on their learning and to gain a sense of ownership and control of their learning, but also establishes learning as a dialogue between the teachers and the learners and among the learners (Graves 2000).

Another area of controversy in teaching at this level is the nature of language teaching activities introduced by the teacher in the classroom. The sizes of the classrooms constrain the introduction of sound communicative language teaching activities. This compounds to the problem of lack of course materials which punctures the possibilities of maximising learning opportunities. Classes range between 200 and 800 students per teacher, a situation that makes the teaching/learning experience an insurmountable challenge both at the level of the students and the teacher. What makes the matter complicated at this level is not only the classroom sizes, but the 
conflict that often arises between the teachers and the learners. While $97.32 \%$ of the students hold that teachers do not teach well, $97.3 \%$ of the teachers state that students disturb a lot in class.

It is not unusual for attempts to try to establish a causal relationship between learners' disturbance and their assessment of teaching methodologies. In short, is it possible to posit that students disturb in class because the teachers do not teacher well or they do not teach well because the students disturb a lot? While the two are reciprocally causative and resultant, there is more reason to believe that classes are boring to the students because the teachers do not teach well. Take for example, $87.36 \%$ of learners sampled asserted that there are no possibilities for the classroom to cause an improvement on their state of English. Learners going into the classroom with this state of mind are definitely just going to satisfy an academic requirement as attested by $89.1 \%$ of the teachers and not to learn the language.

The data also suggest conflicting roles and cultural confrontation between the teachers and the learners. Some of the open comments provided by the teachers identify the students as boring $(86.32 \%)$, rowdy $(78.26 \%$, disrespectful (69.1\%), indiscipline $(92.35 \%$ ) and that they refuse to do their homework (83\%). This signals a generational conflict. Reilly (2012) describes such students as Generation - Y and observes that this generation, values comfort and informality over rules and deadlines and that it prefers to work smarter than harder. The teachers on their part strictly fall within the class of 'digital immigrants' who think in strict discipline terms. While a generational conflict is held to be the cause of the discrepancy in expectation, it also worth noting that most of the teachers, handling this course are Anglophones who have been brought up within the colonial tradition of "obedience before complaint" and are often embarrassed when they are confronted with students who attribute respect to personality than to human values. Hedge (2000: 29ff) notices that the precise interpretations of the functions of a teacher in the classroom would also be to some extent socially and culturally dependent. She states:

It is when there is tension between the requirements of the learning tasks for teacher behaviour and cultural expectations of what is appropriate teacher behaviour that problems can arise from both teachers and learners. ... and for the students to accept that a teacher sits with them as they work together in class requires a corresponding change in their perceptions of authority and responsibility.

It is also important to pin-point the conflicting relationship between learners' learning preferences and what the teachers offer in the classroom. $61 \%$ of the learners sampled expect to be taught through tasks, yet only approximately $10 \%$ of the teachers use task-based instruction in their classrooms. Notice that "the qualities of activities used in language classes and the way these activities are administered make an enormous difference in students' attitudes towards learning" (Dörnyei 2003: 15). Dörnyei also notices that while learners are engaged in executing a task, they continuously appraise the process, and when the ongoing monitoring reveals that progress is slowing, halting, or backsliding, they activate the action control system to "save" or "enhance action."

Although $52.2 \%$ of the learners prefer to be given homework, $83 \%$ of the teachers state that the learners never do their home work. Sometimes the choice and target of the home work matters in how it engages the learners. Graves (2000: 18) examines constraints Ali (an Iranian teacher) faced in a context and states that these constraints forced him to make choices about what to teach and how to teach what was often in conflict with some of the beliefs he held about the nature of language and the purpose for learning. Sometimes learners never really settle on their homework not only because it is cognitively challenging, but most probably, because it does not excite their feelings and stimulate learning.

A more crucial issue suggested by the data is lack of professionalism by the teachers. $1 / 3$ of the teachers handling this course (from the sampling) are trained as secondary school teachers with barely limited knowledge on the nature and purpose of language learning and how learning language as adult might be different from the experiences of young learners. For $69 \%$ of the teachers to say that they do not introduce communicative activities in their classrooms because the prescribed course book does not have any such activities actually demonstrates their limited understanding of communicative language teaching. It is indisputable that the large sizes of the classrooms and learners' unwillingness to acquire pedagogic materials pose serious problems for teachers to exercise their duties. This requires that the whole context of teaching be problematised. Problematising is rooted in the assumption that the teacher who teaches the course is best equipped to understand its challenges and to mobilise the resources available to meet those challenges. The more information you have about the context, the more apparent the challenges will be, and the better you will be able to define and address the challenges as you design and teach the course (Graves 2000: 20).

\section{Conclusion}

The primary interest of this paper was to examine the relationship between learners' attitudes and pedagogic 
practices at the University of Yaounde 1. Francophones' quest for English as observed by previous researchers is not supported at the university level where much is expected. The data in this study suggest that teachers expect to meet fully motivated learners with sustainable positive attitudes driven by out-of-classroom factors. Previous research on the process orientation of attitudes and motivation posit a causal relationship between learners' attitudes towards English and classrooms activities (Rodiki 2006, Xu 2010). That is, the type of activities introduced in the classroom can cause learners to develop negative or positive attitudes towards English. Although this is also partly due to the learning resources offered by classrooms, much of it depends on how the resources are manipulated to create optimal learning environments. This study argues that teachers' inability to adapt the physical and social realities to meet learners' expectations in the learning process is the result of three main factors: inadequate training; confusion about what the course purports to offer; the purpose and nature of language learning. This has resulted in conflicting tendencies between the teachers and learners to the extent that the primary intentions of the course- to facilitate communication in the 'other' language, is deviated. Consequently, the classroom rather frustrates learners' desires to learn, resulting in their negative attitudes towards English. The total outcome is that the relative value the learners have for English is downplayed.

\section{Recommendations}

The problems identified in the course so far can be summarised into two: government policy and professionalism. The problem of large classes is the result of demographic explosion and increasing awareness in education. As more and more children graduate from secondary schools and are indiscriminately absorbed into the university, very little reaction is taken to improve on infrastructure; reason why the classes continue to get larger and larger. The most difficult problem that is posed by the classroom sizes is lack of attention from students. As Safotso (2011) notes, the challenges posed by classroom sizes would be reduced if academic authorities divided the classes into manageable groups. Yet this would pose a more serious problem of the availability of lecture halls which are far from adequate.

Thinking about government's reaction to the problem seems far fetched, given that government policy towards this is usually fraught with high level protocol and bureaucratic procedures. Rather, reflecting on how to deal with the situation at hand to reduce tension between the learners and the teachers offers a better option. This begs the question of training and general pedagogic material. A frequent problem confronted in ELT today, which unfortunately has received little attention, is the problem of large classroom, lack of appropriate teaching resources. Garcia (2008) is referenced by Milambiling (2011:19) as suggesting that besides knowing about languages, subject matter, and teaching methodology, instructors should have "an understanding of the political struggles and social circumstances of students' schools and communities". As researchers keep suggesting that class sizes be reduced, the number of students per class keeps increasing. Rather than adopt this passive approach to the problem, a more situated framework for teacher training that takes into account the reality of teaching and learning situation needs to be developed by training institutions.

A practical and on-the-spot way to deal with the situation is the way input is presented to the learners to invite their attention. Notice that if input receives more attention when it comes from the teacher, there are implications for classroom management (Hedge 2000). A consensus reached by many scholars (Van Patten 1994, Ayoun 2001, Long 2001, for example) is that the best way to get learners attend to input (even in large classes) is to alter it in a way that encourages them to attend to target items through focus on meaning. This way, the activities in the classroom should be intended to change the learners' negative processing strategies and focus their attention on the form-meaning connection such that they discover why certain structures they are working on might be learned when they make sense (Garcia 2008).

Not only is it important to present input in ways that can pull their attention, but sustaining the attention has direct impact on attitudinal resources. To this effect I draw from Jimenez and Mendez (1999: 237) who see attention both as selective and mental effort. Selective insinuate process, which is definable in tasks. Task-based instruction (see Bygate, Skehan, and Swain 2001) in adult classes can reduce distraction and 'rowdiness' if the tasks target the language point through some social phenomenon which students are familiar with or some social problems which students at this level usually encounter.

Students at this level find a lot of interest being subjected to cognitive tasks about the systems of the language they are learning and are more likely to attend to form through meaning as demonstrated by Van Patten (1990). This will reduce the degree of distraction in the classroom and cultivate general interest in the course. Teachers should be able to make a list of problems students at this level generally face and use these problems to seek solutions in the classroom. For example, in one of my classes with over 700 students $^{1}$, I asked them to give advice to a friend, classmate, or relative in the third year who finds him/herself in the following situation: $S / h e$ 
has just got a lucrative job at a bank towards the end of the second semester when he/she is preparing to write the final year exams that will earn him/her the Bachelor's Degree. The job warrants the candidate to start immediately. The friend, classmate, relative is confused whether to accept the job and abandon the long awaited semester exam or take on the job and go without a Bachelor's Degree for life. At the same time s/he needs money as nobody will take care of him/her upon completion of her First Degree programme.

Over $80 \%$ of the students have this experience and are aware of the unemployment rate of the country. They also know how difficult it is to have a job in Cameroon. Most of them had studied in abject poverty all through the course. While they were trying to write sentences to advise the person in question, I used the context to teach them how to give advice in English. They were subsequently asked to debate their solutions in pair work and see whose solution was the best. The degree of involvement in the lesson was far more than I had initially thought. When I elicited the solutions they had written and was working on their sentences to come up with strategies of giving advice in English, I noticed an overwhelming high degree of attention from students I earlier knew to be rowdy. It is not my interest here to say here that the lesson was $100 \%$ successful. Rather, I intend to say that strategies as such tend to reduce the degree of rowdiness in the classroom and impact on learners' attitudes towards the course. Research in the domain of language learning needs to pay attention to learning situations where the physical and social space constrain the possibilities for learners' affective states to be influenced by pedagogic resources in order to provide more situated and effective dimensions to teaching as well as teacher training in such contexts.

\section{References}

Anchimbe, E. (2005). Anglophonism and Francophonism: The stakes of (official) language identity in Cameroon. ALIZES: Revue Angliciste de la Réunion, 25(26), 7-26.

Anchimbe. (2006). Cameroon English: Authenticity, Ecology and Evolution. Munchen: Peter Lang.

Ayoun, D. (2001). The role of negative and positive feedback in the second language acquisition of passé composé and imparfait. The Modern Language Journal, 85, 226-243. http://dx.doi.org/10.1111/0026-7902.00106

Bernaus, M., Masgoret, A., Gardner, R. C., \& Reyes, E. (2004). Motivation and attitudes towards learning languages in multicultural classrooms. The International Journal of Multiculturalism, 1(2), 75-89. http://dx.doi.org/10.1080/14790710408668180

Brown, H. D. (2000). Principles of Language Learning and Teaching (4th ed). NY Addison Wesley: Longman.

Bygate, M., Skehan, P., \& Swain, M. (2001). Researching pedagogic tasks. Second Language Learning, Teaching and Testing. London: Peterson Education Limited.

Carkin, S. (2005). English for academic purposes. In Hinkel (Ed.), Handbook of Research in Second Language Teaching and Learning (pp. 85-98). Mahwah: Lawrence Erlbaum Associates Publishers.

Carreira, M. J. (2005). New framework of intrinsic/extrinsic and instrumental motivation in second language acquisition. The Keiai Journal of International Studies, 16, 39-64.

De Bot, K., Lowie, W., \& Verspoor, M. (2005). Second Language Acquisition. New York: Routledge.

Dörnyei, Z. (1990). Conceptualising motivation in foreign language classroom. The Modern Language Journal, 40, 46-78.

Dörnyei, Z. (2002). The motivational basis of language learning tasks. In Robinson, P. (ed.), Individual Differences in second Language Learning (pp. 137-158). Amsterdam: John Benjamins.

Dörnyei, Z. (2003). Attitudes, orientation, and motivation in language learning: Advances in theory, research, and applications. In Dörnyei, Z. (ed.), Attitudes, Orientation, and Motivation in Language Learning (pp. 3-32). Oxford: Blackwell.

Dörnyei, Z., \& Otto, I. (1998). Motivation in action: A process model of L2 motivation. Working Papers in Applied Linguistics, 4, 43-69. London: Thames Valley University.

Dörnyei, Z., Csizer, K., \& Neineth, N. (2006). Motivation, Language Attitudes and Globalisation: A Hungarian Perspective. Cleavedon: Multilingual Matters.

Faculty of Arts, Letters and Social Sciences. (2007). Programmes L.M.D. Année académiques 2007-2008. Université de Yaoundé 1.

Garcia, R. (2008). Input processing and output processing in second language acquisition: A case for the Spanish 
subjunctive. $33^{\text {rd }}$ International Laud Symposium: Cognitive Approaches to Second/Foreign Language Processing: Theory and Pedagogy, 409-428.

Gardner, R. C. (1985). Social Psychology and Second Language Learning: The Role of Attitude and Motivation. London: Edward Arnold.

Gardner, R. C. (2004). Attitude/Motivation Test Battery. International AMTB Research Project.

Gardner, R. C., \& MacIntyre, P. D. (1993). A student's contribution to second language learning. Part II: Affective variables. Language Teaching, 26, 1-11. http://dx.doi.org/10.1017/S0261444800000045

Gardner, R. C., \& Lambert, W. B. (1972). Attitudes and Motivation in Second Language Learning. Rowley Massachusetts: Newbury House Publishers.

Graves, K. (2000). Designing Language Courses: A Guide for Teachers. London: Heinle and Heinle.

Hedge, T. (2000). Teaching and Learning in the Language Classroom. Oxford: Oxford University Press.

Jimenez, L., \& Mendez, C. (1999). Which attention is needed for implicit learning. Journal of Experimental Psychology: Learning, Memory, and Cognition, 25(1), 236-259. http://dx.doi.org/10.1037/0278-7393.25.1.236

Littlewood, W. (2006). Communicative and task-based language teaching in East Asian classrooms. Language Teaching, 40(3), 243 -249. http://dx.doi.org/10.1017/S0261444807004363

Long, M. (2001). Focus on Form: A design feature in language teaching methodology. In Candlin, C., \& N. Mercer (eds.), English Language Teaching in its Social Context: A Reader (pp. 180-190). London: Routledge.

Milambiling, J. (2011). Bringing one language to another: Multilingualism as a resource in the language classroom. Forum, 49(1), 18-25.

Mitchell, R., \& Myles, F. (1998). Second Language Learning Theories. London: Arnold.

Noels, K. A. (2001). Learning Spanish as a second language: learners' orientations and perception of their teachers' communication style. Language Learning, 51, 107-144. http://dx.doi.org/10.1111/0023-8333.00149

Oller, J., \& Perkins, K. (1978). Intelligence and language proficiency as sources of variance in self-reported affective variables. Language Learning, 28, 85-87.

Pintrich, P. R., \& Schunk, D. H. (2002). Motivation in Education: Theory, Research, and Applications (2 ${ }^{\text {nd }}$ ed.). Englewood Clifs: NJ prentice Hall.

Reilly, P. (2012). Understanding and teaching generation Y. Forum, 50(1), 2-11.

Rivers, W. (1964). The Psychologist and the Foreign Language Teacher. Chicago: University of Chicago Press.

Rodiki, P. J. (2006). Attitudes and motivation and their impact on the performance of young English as a foreign language learners. Journal of Language and Learning, 1(5), 1-20.

Safotso, G. T. (2011). Evaluating English for Academic Purposes in some Cameroonian Universities. Journal of Education and Practice, 2(7), 62-72. Retrieved Friday, 7 September 2012 from $\mathrm{http}: / /$ www.iiste.org/565-1430-1-SM

Shuman, J. H. (1998). A neurobiological perspective on effect and methodology in second language learning. In Arnold, J. (Ed.), Affect in Language Learning (pp. 28-42). Cambridge: Cambridge University Press.

Simo Bobda, A. (2001). Various statuses and perceptions of English in Cameroon: A diachronic and synchronic analysis. TRANS, Internet-Zeitschrift fur Kulturwissenschaften, 11. Retrieved Monday, 22 February 2012 from http://www.inst.at/trans/11 Nr/bobda11.htm

Smit, U., \& Dalton, C. (2000). Motivational patterns in advanced EFL pronunciation learners. IRAL, 38, 229-246.

Svanes, B. (1987). Motivation and cultural distance in second-language acquisition. Language Learning, 37, 341-359.

Thanasoulas, D. (2002). Motivation and motivating in EFL. The Internet TESL Journal, 8(11), 8. Retrieved June 8, 2012 from http://www.iteslj.org/Articles/Thanasoulas-Motivation.html

Thornubury, S. (2006). An A-Z of ELT. Oxford: Macmillan. 
Facultes des Arts, Lettres et Sciences Humaines. (2007). Programmes LMD 2007/2008. University of Yaounde 1.

Ushida, E. (2005). The role of students' attitudes and motivation in second language learning in online language courses. CALICO Journal, 23(1), 49-78.

Van Patten, B. (1990). Attending to form and content in the input. Studies in Second Language Acquisition, 12, 287-301. http://dx.doi.org/10.1017/S0272263100009177

Van Patten, B. (1994). Evaluating the role of consciousness in second language acquisition; terms, linguistic features and research methodology. In Hulstijn, J., \& R. Schmidt (Eds.), Consciousness in Second Language Learning, AILA, 11, 27-36.

Weiner, B. (1992). Human Motivation: Metaphors, Theories and Research. Newbury Park, CA: Sage.

$\mathrm{Xu}, \mathrm{H}$. (2010). From EFL to ESL: The influence of context on learners' motivational profiles. Arizona Working Papers in SLA and Teaching, 17, 123-142.

Note

Note 1. This applies to a class I taught in the 2011/2012 academic year and might not reflect the current situation since efforts are being made to reduce class sizes for effective language teaching.

\section{Appendix}

\section{Questionnaire pour étudiants}

Ce questionnaire vise à avoir vos impressions et votre opinion dans l'apprentissage de l'anglais pour la Formation Bilingue. Notre intérêt est purement académique. Nous vous prions d'être autant précis que possible dans vos réponses. Coche seulement où votre opinion est pleinement respectée.

\section{BUTS}

\begin{tabular}{|l|l|l|l|l|l|}
\hline $\begin{array}{l}\mathbf{N} \\
0\end{array}$ & Affirmation & $\begin{array}{l}\text { Extrêmement } \\
\text { contre }\end{array}$ & Contre & $\begin{array}{l}\text { Extrêmement } \\
\text { d'accord }\end{array}$ & D'accord \\
\hline 1 & $\begin{array}{l}\text { Actuellement, il est nécessaire que l'anglais soit enseigné dans } \\
\text { votre département }\end{array}$ & & & \\
\hline 2 & L'accent doit être mis sur la langue parlée & & & & \\
\hline 3 & L'accent doit être mis sur la langue écrite & & & \\
\hline & $\begin{array}{l}\text { L'anglais ne doit pas être enseigné dans mon département } \\
\text { parce que: }\end{array}$ & & & \\
\hline 4 & Je sais déjà parler & & & \\
\hline 5 & Je ne comprends pas & & & \\
\hline 6 & L'anglais réduit mes points & & & \\
\hline 7 & l'anglais ne m'aide en aucun cas & & \\
\hline 8 & Je n'aime pas du tout & & \\
\hline 9 & Les enseignants n'enseignent pas bien & & \\
\hline 10 & l'enseignant devrait nous donner des devoirs à faire à la maison & & & \\
\hline 11 & $\begin{array}{l}\text { L'enseignant devrait nous laisser jouer au game, faire du } \\
\text { théâtre, chanter des sons en classe }\end{array}$ & & & \\
\hline 12 & $\begin{array}{l}\text { L'enseignant devrait prendre plus de temps pour expliquer les } \\
\text { règles grammaticales }\end{array}$ & & & \\
\hline 13 & $\begin{array}{l}\text { L'enseignant devrait nous donner plus d'opportunité pour } \\
\text { parler }\end{array}$ & & & \\
\hline 14 & $\begin{array}{l}\text { L'enseignant devrait nous occuper durant l'heure de cours avec } \\
\text { des tâches que de nous expliquer les règles }\end{array}$ & & & \\
\hline 15 & $\begin{array}{l}\text { Je fais ce cours seulement parce qu'il est instauré par } \\
\text { l'institution }\end{array}$ & & & \\
\hline 16 & $\begin{array}{l}\text { A travers ce cours, je pense que mon niveau en anglais se fera } \\
\text { remarquer /s'améliorera }\end{array}$ & & & \\
\hline 17 & Mes leçons en anglais sont très intéressantes & & & \\
\hline 18 & L'anglais est une langue difficile & & \\
\hline 19 & L'anglais est aussi comme toutes autres langues & & \\
\hline 20 & L'anglais est une langue facile & & \\
\hline 21 & Mon niveau en anglais est excellent & & & \\
\hline 22 & Mon niveau en anglais est très bon & & & \\
\hline 23 & Mon niveau en anglais est seulement bien & & & \\
\hline 24 & Mon niveau en anglais est très mauvais & & & \\
\hline 25 & Mon niveau en anglais est mauvais & & & \\
\hline
\end{tabular}


\begin{tabular}{|l|l}
\hline 26 & Mon niveau en anglais est moyen
\end{tabular}

\section{Merci}

\section{Students' Questionnaire}

This questionnaire is intended to get your feelings and opinions in learning English for Bilingual Training. Our interest is purely academic. We plead that you try to be as clear as possible in your answers. Tick only where your opinion is fully reflected.

\section{Goals}

\begin{tabular}{|c|c|c|c|c|c|c|}
\hline $\mathbf{N}$. & Statement & $\begin{array}{l}\text { Strongly } \\
\text { disagree }\end{array}$ & disagree & $\begin{array}{l}\text { strongly } \\
\text { agree }\end{array}$ & agree & Neutral \\
\hline 1. & Is it actually necessary for English to be taught in your department & & & & & \\
\hline 2. & More emphasis should be given to speaking & & & & & \\
\hline 3. & More emphasis should be given to writing & & & & & \\
\hline & English should not be taught in my department because & & & & & \\
\hline 4. & I can already speak it & & & & & \\
\hline 5. & I don't understand it & & & & & \\
\hline 6. & It reduces my marks & & & & & \\
\hline 7. & It does not help me in any way & & & & & \\
\hline 8. & I don't like it at all & & & & & \\
\hline 9. & The teachers don't teach well & & & & & \\
\hline 10. & The teacher should give us work to do at home & & & & & \\
\hline 11. & The teacher should let us play games, act drama, sing songs in class & & & & & \\
\hline 12. & The teacher should take more time explaining grammatical rules & & & & & \\
\hline 13. & The teacher should give us more opportunities to speak & & & & & \\
\hline 14. & The teacher should give us tasks to do on our on than explaining rules & & & & & \\
\hline 15. & I am doing this course only because it is an institutional requirement & & & & & \\
\hline 16. & Through this course I believe that my level of English will improve & & & & & \\
\hline 17. & My lessons in English are very interesting & & & & & \\
\hline 18. & English is a difficult language & & & & & \\
\hline 19. & English is just like any other language & & & & & \\
\hline 20. & English is a simple language & & & & & \\
\hline 21. & My level of English is excellent & & & & & \\
\hline 22. & My level of English is very good & & & & & \\
\hline 23. & My level of English is only good & & & & & \\
\hline 24. & My level of English is very bad & & & & & \\
\hline 25. & My level of English is bad & & & & & \\
\hline 26. & My level of English is average & & & & & \\
\hline
\end{tabular}

\section{Teachers' Questionnaire}

\begin{tabular}{|c|c|c|c|c|c|c|}
\hline N. & Statements & $\begin{array}{l}\text { strongly } \\
\text { agree }\end{array}$ & agree & $\begin{array}{l}\text { strongly } \\
\text { disagree }\end{array}$ & disagree & Nutral \\
\hline 1. & Students love English & & & & & \\
\hline 2. & The students do their home work regularly & & & & & \\
\hline 3. & Students participate well in class & & & & & \\
\hline 4. & Students don't come to class regularly & & & & & \\
\hline 5. & Students disturb a lot in class & & & & & \\
\hline 6. & Students undermine Bilingual Training & & & & & \\
\hline 7. & Students are only out to satisfy an academic requirement & & & & & \\
\hline 8. & $\begin{array}{l}\text { Students disturb whenever I try to introduce communicative } \\
\text { activities }\end{array}$ & & & & & \\
\hline 9. & The classes are too large for communicative activities & & & & & \\
\hline 10. & $\begin{array}{l}\text { The structure of the classes does not permit the introduction of } \\
\text { Communicative Activities }\end{array}$ & & & & & \\
\hline 11. & $\begin{array}{l}\text { I don't introduce communicative activities are because the text } \\
\text { book does not have them }\end{array}$ & & & & & \\
\hline 12. & Students are not interested in communicative activities & & & & & \\
\hline
\end{tabular}




\begin{tabular}{|l|l|l|l|l|l|l|}
\hline & Statements & $\begin{array}{l}\text { in all } \\
\text { lessons }\end{array}$ & $\begin{array}{l}\text { in most } \\
\text { lessons }\end{array}$ & $\begin{array}{l}\text { in few } \\
\text { lessons; }\end{array}$ & $\begin{array}{l}\text { in no } \\
\text { lesson }\end{array}$ & \\
\hline 13. & I introduce games & & & & & \\
\hline 14. & I introduce songs & & & & & \\
\hline 15. & I introduce pair/group work and role plays & & & & & \\
\hline 16. & I give home work & & & & & \\
\hline 17. & I follow the prescribed course book strictly & & & & & \\
\hline 18. & The students own the prescribed course book & & & & & \\
\hline 19. & I teach grammar & & & & & \\
\hline 20. & I teach vocabulary & & & & & \\
\hline 21. & I teach pronunciation & & & & & \\
\hline 22. & I teach writing & & & & & \\
\hline 23. & I teach speaking & & & & & \\
\hline 24. & I teach Listening & & & & & \\
\hline
\end{tabular}

